\title{
Enterococcus hirae, a New Species That Includes Amino Acid Assay Strain NCDO 1258 and Strains Causing Growth Depression in Young Chickens
}

\author{
JOHN A. E. FARROW AND MATTHEW D. COLLINS* \\ Department of Microbiology, National Institute for Research in Dairying, Shinfield, Reading RG2 9AT, United Kingdom
}

\begin{abstract}
Deoxyribonucleic acid base composition, deoxyribonucleic acid-deoxyribonucleic acid hybridization, lipid, and biochemical studies were performed with Enterococcus faecium NCDO 1258 (= Snell strain R) and other atypical Enterococcus faecium strains from pigs and chickens in an attempt to clarify their taxonomy. Our results indicate that these strains constitute a new species, for which the name Enterococcus hirae sp. nov. is proposed. The type strain of Enterococcus hirae is strain NCDO 1258.
\end{abstract}

Until recently, Enterococcus (Streptococcus) faecium was considered to represent a well-defined taxon (10) and encompassed strains previously designated "Streptococcus durans" (14). However, recent deoxyribonucleic acid (DNA)DNA hybridization studies $(4,11)$ have shown that Enterococcus faecium and " $S$. durans" are distinct entities, and the latter taxon has been designated Enterococcus durans (2). There are a number of atypical "Enterococcus faecium" strains which cannot be allocated unequivocally to either of these taxa $(4,11,12)$. Schleifer and Kilpper-Bälz (12) reported that three strains designated Enterococcus faecium shared a relatively low level of DNA homology (ca. 40\%) with the type strain of Enterococcus faecium and suggested that these strains may represent a distinct species. However, an examination of the histories of the strains (strains DSM 20160, CCM 2423, and CCM 2424) studied by these workers revealed that all were derived from a common strain (Snell strain $\mathrm{R}^{\mathrm{T}}\left[\mathrm{T}=\right.$ type strain]). Snell strain $\mathrm{R}^{\mathrm{T}}$ (= NCDO $\left.1258^{\mathrm{T}}\right)$ also was shown to be genotypically distinct from the type strains of Enterococcus faecium and Enterococcus durans by Farrow et al. (4). The taxonomic position of some enterococci which cause growth depression in young chickens $(5,9)$ is also equivocal. Although these strains are referred to in the literature as Streptococcus faecium $(5,9)$, their biochemical properties are intermediate between those of Enterococcus faecium and Enterococcus durans. Thus, there is considerable interest to determine whether these chicken isolates along with Snell strain $R^{T}$ constitute the nucleus of a new species.

In the present study DNA base composition, DNA-DNA homology, lipid, and biochemical studies were performed with the atypical Enterococcus faecium strains described above and with some unclassified group D streptococci (Sharpe-Fewins serological types 26C and 39) (13). Our results indicate that these strains represent a new species, for which the name Enterococcus hirae sp. nov. is proposed.

\section{MATERIALS AND METHODS}

Strains. The test strains shown in Table 1 were obtained from the National Collection of Dairy Organisms, Shinfield, Reading, United Kingdom.

DNA base composition and DNA-DNA hybridization. To prepare DNA, we used a modification (4) of the method of Garvie (6). DNA base composition was estimated by thermal denaturation in standard saline citrate, as described by

\footnotetext{
* Corresponding author.
}

Garvie (7), using DNAs from Leuconostoc mesenteroides NCDO 768 and Escherichia coli K-12 strain NCDO 1984 as standards. DNA-DNA hybridizations were performed under optimum conditions $\left(25^{\circ} \mathrm{C}\right.$ below the melting temperature) and stringent conditions $\left(10^{\circ}\right.$ below the melting temperature) by using the membrane filter technique described previously (8).

Fatty acid analyses. Cells for fatty acid analyses were grown in yeast extract-phosphate broth (7) supplemented with $0.5 \%(\mathrm{wt} / \mathrm{vol})$ glucose at $30^{\circ} \mathrm{C}$ for 2 days. Fatty acid methyl esters were prepared from dry cells $(50 \mathrm{mg})$ by acid methanolysis and were analyzed by gas-liquid chromatography as described previously (3).

Biochemical tests. The tests were performed by using the API 20 STREP and API 50CH systems (API Products, Basingstoke, United Kingdom) according to the instructions of the manufacturer. Tests were incubated at $37^{\circ} \mathrm{C}$, and readings were made at 4,24 , and $48 \mathrm{~h}$.

\section{RESULTS AND DISCUSSION}

The DNA base compositions of the test strains are shown in Table 1. Enterococcus hirae NCDO $1258^{\mathrm{T}}$, NCDO 1631, NCDO 1648, NCDO 2683, and NCDO 2708 had a guanineplus-cytosine content range of 37 to $38 \mathrm{~mol} \%$. These data are within the range of 37 to $45 \mathrm{~mol} \%$ guanine plus cytosine reported for the genus Enterococcus and similar to the values reported for Enterococcus faecium and Enterococcus durans $(2,4,12)$.

The specific activity of $\left[{ }^{3} \mathrm{H}\right] \mathrm{DNA}$ from strain NCDO 2708 was approximately $2,600 \mathrm{cpm} / \mu \mathrm{g}$. Snell strain $\mathrm{R}^{\mathrm{T}}$ (= NCDO $1258^{\mathrm{T}}$ ), the chicken isolates (strains NCDO 2683 and NCDO 2708), and representative strains of Sharpe-Fewins serotypes 26C and 39 (13) formed a single DNA homology group that was approximately 70 to $100 \%$ related to strain NCDO 2708 (Table 2). These strains shared relatively high levels of homologies (58\%) with Enterococcus faecium NCDO $942^{\mathrm{T}}$ and Enterococcus durans NCDO $596^{\mathrm{T}}$ under optimum hybridization conditions; these values decreased to $<30 \%$ under stringent conditions, indicating that the former strains are genetically distinct. It is worth noting that under stringent hybridization conditions four Enterococcus hirae strains (strains NCDO $1258^{\mathrm{T}}$, NCDO 1648, NCDO 2683, and NCDO 2708) were approximately 85 to $100 \%$ related to strain NCDO 2708, but Enterococcus hirae NCDO 1631 (SharpeFewins serotype $26 \mathrm{C}$ ) was only $43 \%$ related to the latter. Therefore, strain NCDO 1631 is best considered a peripheral member of this homology group. 
TABLE 1. Strain details and DNA base compositions

\begin{tabular}{|c|c|c|c|}
\hline Species & Strain & Other designation(s) and comments & $\begin{array}{l}\text { Guanine-plus- } \\
\text { cytosine } \\
\text { content } \\
(\mathrm{mol} \%)\end{array}$ \\
\hline \multirow[t]{5}{*}{ Enterococcus hirae } & $\mathrm{NCDO} 1258^{\mathrm{T}}$ & $\begin{array}{l}\text { Snell strain } \mathrm{R}^{\mathrm{T}} \text {; ATCC } 8043^{\mathrm{T}} \text {, ATCC } \\
9790^{\mathrm{T}} ; \text { NCIB } 6459^{\mathrm{T}} \text {, NCIB } 8123^{\mathrm{T}}, \mathrm{NCIB} \\
8191^{\mathrm{T}}, \text { CCM } 2423^{\mathrm{T}}, \text { CCM } 2424^{\mathrm{T}} \text {; DSM } \\
20160^{\mathrm{T}}\end{array}$ & $38^{a}$ \\
\hline & NCDO 1631 & $\begin{array}{l}\text { PG39; Sharpe-Fewins serotype } 26 C \text {; from } \\
\text { pig intestine }\end{array}$ & 38 \\
\hline & NCDO 1648 & $\begin{array}{l}\text { PG } 48 \text {; Sharpe-Fewins serotype } 39 \text {; from } \\
\text { pig intestine }\end{array}$ & 37 \\
\hline & NCDO 2683 & $2 \mathrm{SY} 3 ;$ Fuller isolate from chicken crop & 37 \\
\hline & NCDO 2708 & SY1; Fuller isolate from chicken crop & 37 \\
\hline Enterococcus avium & NCDO $2369^{\mathrm{T}}$ & & $40^{c}$ \\
\hline Enterococcus casseliflavus & NCDO $2372^{\mathrm{T}}$ & & $43^{a}$ \\
\hline Enterococcus durans & NCDO $596^{\mathrm{T}}$ & & $38^{a}$ \\
\hline Enterococcus faecalis & NCDO $581^{\mathrm{T}}$ & & $39^{a}$ \\
\hline \multirow{2}{*}{ Enterococcus faecium } & NCDO $942^{\mathrm{T}}$ & & $38^{a}$ \\
\hline & NCDO 1632 & $\begin{array}{l}\text { CH12; Sharpe-Fewins serotype } 27 \text {; from } \\
\text { canned ham }\end{array}$ & 39 \\
\hline Enterococcus gallinarum & NCDO $2313^{\mathrm{T}}$ & & $40^{a}$ \\
\hline Enterococcus malodoratus & NCDO $846^{\mathrm{T}}$ & & $40^{a}$ \\
\hline Enterococcus sp. & NCDO 2138 & Roguinsky strain $47-16$ & 40 \\
\hline
\end{tabular}

"Data from reference 4 .

The results of our study confirm the results of studies done by Schleifer et al. $(11,12)$ and Farrow et al. (4), who demonstrated that Snell strain $\mathrm{R}^{\mathrm{T}}\left(=\mathrm{NCDO} 1258^{\mathrm{T}}=\mathrm{CCM}\right.$ $2423^{\mathrm{T}}$ ) is genotypically distinct from Enterococcus faecium and Enterococcus durans. The data further suggest that the chicken isolates of Fuller and colleagues $(5,9)$ and unclassified group D streptococci of Sharpe and Fewins (13) are closely related to Snell strain $\mathrm{R}^{\mathrm{T}}$. Taking $70 \%$ homology under optimum hybridization conditions as the border line for species differentiation, Snell strain $\mathrm{R}^{\mathrm{T}}$, the chicken isolates, and the group D streptococci of Sharpe and Fewins are members of a single genetic species. The name Enterococcus hirae is proposed for these strains.

Description of Enterococcus hirae sp. nov. Enterococcus hirae (hir.ae. L.gen.s.n. hirae of the intestine or gut) cells are ovoid and occur mostly in pairs or short chains. The cells are gram positive and nonmotile. Surface colonies on blood or nutrient agar are circular, smooth, and entire. Nonhemolytic. Catalase negative. Growth occurs at 10 and $45^{\circ} \mathrm{C}$, in $6.5 \% \mathrm{NaCl}$, and at $\mathrm{pH}$ 9.6. Facultatively anaerobic. L-Lactic acid is the major end product of glucose fermentation. All strains hydrolyze esculin, are Voges-Proskauer, arginine dehydrolase, $\beta$-galactosidase, leucine arylamidase, and pyrrolidonylarylamidase positive, and produce acid from amygdalin, arbutin, $\mathrm{N}$-acetylglucosamine, cellobiose, fructose, galactose, glucose, $\beta$-gentiobiose, lactose, maltose, mannose, melibiose, ribose, salicin, sucrose, and trehalose. All strains fail to produce acid from adonitol, D-arabinose, L-arabinose, D-arabitol, L-arabitol, dulcitol, erythritol, D-fucose, L-fucose, glycogen, gluconate, inositol, inulin, 2-keto-gluconate, 5-keto-gluconate, D-lyxose, mannitol, $\alpha$ methyl-D-glucoside, $\alpha$-methyl-D-mannoside, $\alpha$-methylxyloside, rhamnose, sorbose, sorbitol, xylitol, D-xylose, and L-xylose, do not hydrolyze hippurate, and are alkaline phosphatase and $\beta$-glucuronidase negative. Variable results are obtained for glycerol (one strain positive), melezitose (one strain positive), raffinose (two strains positive), starch (three strains positive), D-tagatose (one strain positive), and D-turanose (one strain positive). Reacts with Lancefield group D antisera. Group A type peptidoglycan based upon

TABLE 2. Levels of DNA homology of enterococci under optimum and stringent conditions

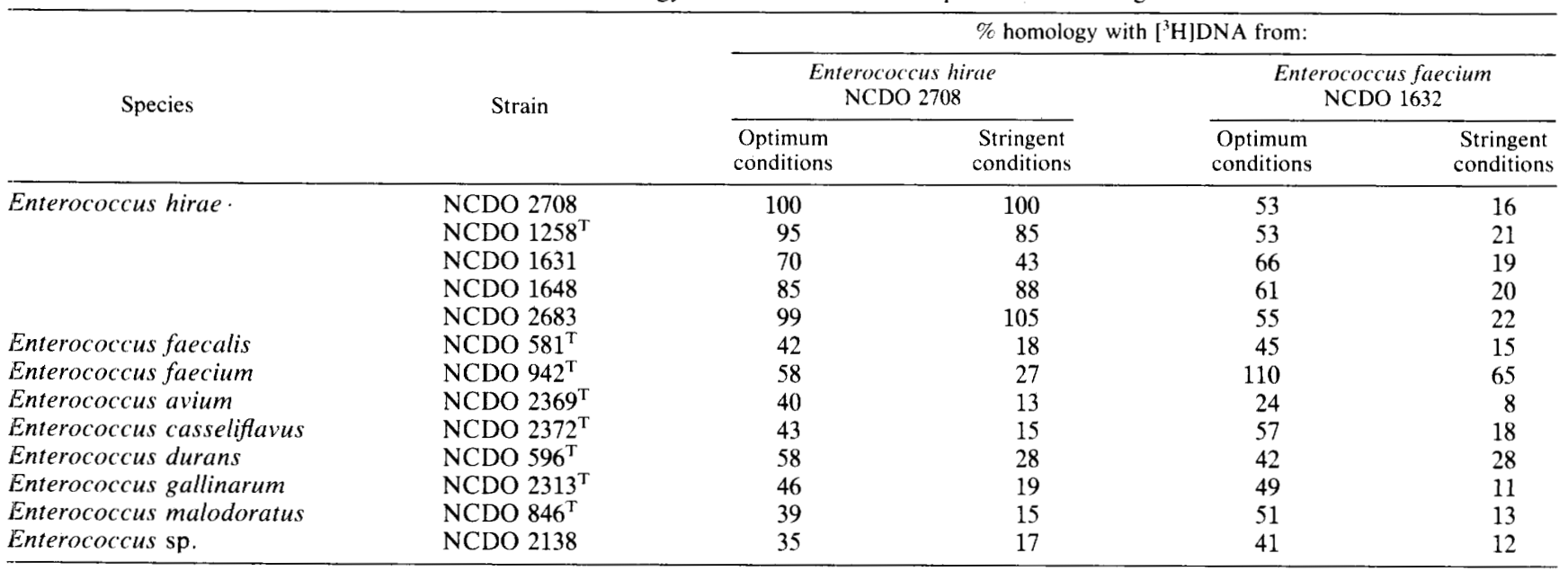


TABLE 3. Percent long-chain fatty acid composition of Enterococcus hirae strains

\begin{tabular}{|c|c|c|c|c|c|c|c|c|c|}
\hline \multirow{2}{*}{ Strain } & \multicolumn{9}{|c|}{ Fatty acid composition $(\%)^{a}$} \\
\hline & $\mathrm{C}_{14: 0}$ & $\mathrm{C}_{15: 0}$ & $C_{16: 0}$ & $C_{16: 1}$ & $C_{17: 0}$ & $\mathrm{C}_{18: 0}$ & $C_{18: 1{ }^{b}}$ & $\mathrm{C}_{18: 1}$ & $\Delta \mathrm{C}_{19}$ \\
\hline NCDO $1258^{\mathrm{T}}$ & 4.4 & 1.5 & 30.4 & 9.1 & 0.5 & 1.5 & 36.6 & 0.1 & 15.9 \\
\hline NCDO 1631 & 5.6 & 1.6 & 35.0 & 11.4 & 0.1 & 1.7 & 28.1 & 0.2 & 16.3 \\
\hline NCDO 1648 & 3.4 & 1.2 & 30.1 & 7.2 & 0.5 & 2.7 & 38.8 & 0.4 & 15.7 \\
\hline NCDO 2683 & 3.1 & 1.8 & 27.7 & 8.1 & 1.0 & 2.2 & 41.2 & 0.2 & 14.7 \\
\hline NCDO 2708 & 3.6 & 2.0 & 28.4 & 7.3 & 0.2 & 1.0 & 39.4 & 0.1 & 18.0 \\
\hline
\end{tabular}

${ }^{a}$ Abbreviations for fatty acids are illustrated by the following examples: $C_{16: 0}$, straight-chain saturated hexadecanoic acid: $C_{18: 1}$, monounsaturated octadecenoic acid; $\Delta \mathrm{C}_{19}$, cis-11,12-methylenoctadecanoic acid.

${ }^{b}$ cis-11,12-Octadecenoic acid.

TABLE 4. Differential characteristics of Enterococcus hirae, Enterococcus casseliflavus, Enterococcus durans, and Enterococcus faecium

\begin{tabular}{|c|c|c|c|c|}
\hline Characteristic & $\begin{array}{c}\text { Enterococcus } \\
\text { hirale }\end{array}$ & $\begin{array}{c}\text { Enterococcus } \\
\text { casseliflavus }\end{array}$ & $\begin{array}{c}\text { Enterococcus } \\
\text { durans }\end{array}$ & $\begin{array}{c}\text { Enterococcus } \\
\text { faecium }\end{array}$ \\
\hline \multicolumn{5}{|l|}{ Acid produced from: ${ }^{a}$} \\
\hline L-Arabinose & $-{ }^{b}$ & + & - & + \\
\hline Glycerol & $\mathrm{v}$ & - & - & + \\
\hline Inulin & - & + & _- & - \\
\hline Melibiose & + & + & - & $\mathrm{v}$ \\
\hline$\alpha$-Methyl-D-glucoside & - & + & - & - \\
\hline Suçose & + & + & - & $\mathrm{v}$ \\
\hline $\begin{array}{c}\text { Hydrolysis of } \\
\text { hippurate }\end{array}$ & - & - & $\mathrm{v}$ & + \\
\hline$\beta$-hemolytic & - & - & $\mathrm{v}$ & - \\
\hline Motile & - & + & - & - \\
\hline Menaquinone composition & - & MK-8,MK-7 & - & - \\
\hline
\end{tabular}

“ Tests performed with API 20 STREP and API 50CH systems.

$b+$, Positive; - , negative; v, variable.

c Test performed with API 20 STREP system.

lysine (type Lys-D-Asp). Menaquinones are absent. The long-chain fatty acids are predominantly of the straightchain saturated, monounsaturated, and cyclopropane ring types. The major fatty acids are hexadecanoic, octadecenoic, and cis-11,12-methylenoctadecanoic acids (Table 3). The guanine-plus-cytosine content of the DNA ranges from 37 to $38 \mathrm{~mol} \%$, as determined by melting temperature. The strains form a distinct homology group, as determined by DNA-DNA hybridization. Isolated from chicken crops and pig intestines. The type strain is strain NCDO 1258 (= E.E. Snell strain R = ATCC $8043=$ CCM $2423=$ DSM 20160).

Description of the type strain. In most respects the description of the type strain resembles the description of the species. The type strain is $\alpha$-galactosidase negative. Acid is produced from starch and D-tagatose. Acid is not produced from glycerol, melezitose, raffinose, or D-turanose. The type strain has complex nutritional requirements and is of industrial importance in the assay of a plethora of amino acids, vitamins, and other compounds (1). Enterococcus hirae is distinguished from Enterococcus casseliflavus, Enterococcus durans, and Enterococcus faecium by the tests shown in Table 4.

\section{LITERATURE CITED}

1. American Type Culture Collection. 1982. Catalogue of strains, 15th ed. American Type Culture Collection, Rockville, Md.

2. Collins, M. D., D. Jones, J. A. E. Farrow, R. Kilpper-Bälz, and K. H. Schleifer. 1984. Enterococcus avium nom. rev., comb. nov.; E. casseliflavus nom. rev., comb. nov.; E. durans nom. rev., comb. nov.; E. gallinarum comb. nov.; and $E$. malodoratus sp. nov. Int. J. Syst. Bacteriol. 34:220-223.

3. Farrow, J. A. E., and M. D. Collins. 1984. DNA base composition, DNA-DNA homology and long-chain fatty acid studies on Streptococcus thermophilus and Streptococcus salivarius. J.
Gen. Microbiol. 130:357-362.

4. Farrow, J. A. E., D. Jones, B. A. Phillips, and M. D. Collins. 1983. Taxonomic studies on some group D streptococci. J. Gen. Microbiol. 129:1423-1432.

5. Fuller, R., M. E. Coates, and G. F. Harrison. 1979. The influence of specific bacteria and a filterable agent on the growth of gnotobiotic chicks. J. Appl. Bacteriol. 46:335-342.

6. Garvie, E. I. 1976. Hybridization between the deoxyribonucleic acids of some strains of heterofermentative lactic acid bacteria. Int. J. Syst. Bacteriol. 26:116-122.

7. Garvie, I. E. 1978. Streptococcus raffinolactis (Orla-Jensen and Hansen), a group $\mathrm{N}$ streptococcus found in raw milk. Int. $\mathbf{J}$. Syst. Bacteriol. 28:190-193.

8. Garvie, E. I., J. A. E. Farrow, and B. A. Phillips. 1981. A taxonomic study of some strains of streptococci which grow at $10^{\circ} \mathrm{C}$ but not at $45^{\circ} \mathrm{C}$ including Streptococcus lactis and Streptococcus cremoris. Zentralbl. Bakteriol. Parasitenkd. Infektionskr. Hyg. Abt. 1 Orig. Reihe 2:151-165.

9. Houghton, S. B., R. Fuller, and M. E. Coates. 1981. Correlation of growth depression of chicks with the presence of Streptococcus faecium in the gut. J. Appl. Bacteriol. 51:113-120.

10. Jones, D. 1978. Composition and differentiation of the genus Streptococcus, p. 1-49. In F. A. Skinner and L. B. Quesnel (ed.), Streptococci. Academic Press, Inc., London.

11. Kilpper-Bälz, R., G. Fischer, and K. H. Schleifer. 1982. Nucleic acid hybridization of group $\mathrm{N}$ and group $\mathrm{D}$ streptococci. Curr. Microbiol. 7:245-250.

12. Schleifer, K. H., and R. Kilpper-Bälz. 1984. Transfer of Streptococcus faecalis and Streptococcus faecium to the genus Enterococcus nov.rev. as Enterococcus faecalis comb.nov. and Enterococcus faecium comb. nov. Int. J. Syst. Bacteriol. 34:31-34.

13. Sharpe, M. E., and B. G. Fewins. 1960. Serological typing of strains of Streptococcus faecium and unclassified group D streptococci from canned hams and pig intestines. J. Gen. Microbiol. 23:621-630.

14. Sherman, J. M., and H. U. Wing. 1937. Streptococcus durans n.sp. J. Dairy Sci. 20:165-167. 